\title{
MENGGLOBALKAN MAKANAN TRADISIONAL LEWAT MEDIA SOSIAL YOUTUBE SEBAGAI BUDAYA TANDINGAN (Studi Food Vlogger Nex Carlos sebagai Media Promosi Kuliner Lokal)
}

\author{
Rochmad Effendy ${ }^{1}$, Putri Ayu Wulandari ${ }^{1}$, Lian Agustina Setiyaningsih ${ }^{1}$, Ana Mariani ${ }^{1}$
}

${ }^{1}$ Program Studi IImu Komunikasi FISIP Universitas Merdeka Malang

Coresponding author: Lian Agustina Setiyaningsih lian.agustina@unmer.ac.id

\begin{abstract}
Globalization, the massive, systematic spread of American culture and its lifestyle throughout the world. The activity of consuming fast food is constructed as a modern, current and global lifestyle through regulatory capture and deep capture through advertising. Propaganda through communication media make cultural colonization by homogenizing food tastes in the world, so delegitimizes and distorts local food prestige. People no longer see traditional food as cultural identity. This study examines YouTuber Carlos in popularizing traditional foods to foreign countries. The qualitative descriptive approach with observation, document and literatures reviews and interviews with informants. This study finds that Nex Carlos' Youtube account functions effectively in globalizing local food with well interactive communication and intimate emotional bonds. Para social interaction makes viewers see food vlogger as role model, counselor, and entertained which leads to recommended adoption. As a cultural product, local culinary consumption been seen as counterculture to the incessant global fast food propaganda. The social learning are about ecological, social and political awareness-pedagogy for guaranteeing the food sustainability.
\end{abstract}

Key Words: Food Vlogger, Globalization, Homogenization, Para Social Interaction, Pedagogy of Food

\begin{abstract}
Abstrak: Globalisasi, penyebarluasan masif dan sistematis budaya, gaya hidup Amerika ke seluruh dunia. Kegiatan mengkonsumsi makanan siap saji dikonstruksikan sebagai gaya hidup modern, terkini dan mendunia melalui regulatory capture dan deep capture melalui periklanan. Propaganda melalui media komunikasi merupakan penjajahan kultural melalu hegemoni selera makanan sehingga mendelegitimasi dan mendistorsi gengsi makanan lokal, sehingga bukan lagi identitas budaya. Penelitian ini mengkaji cara kerja media sosial Nex Carlos dalam mempopulerkan makanan tradisional ke luar negeri. Metode penelitian deskriptif kualitatif dengan pengamatan, dokumen, wawancara dengan informan. Hasilnya adalah Youtube Nex Carlos berfungsi efektif mengglobalkan makanan lokal secara interaktif dan intim. Interaksi para sosial membuat penonton memandangnya sebagai model panutan, konselor dan penghibur sehingga mengadopsi rekomendasinya. Sebagai produk budaya, konsumsi kuliner lokal dipandang budaya tandingan atas propaganda makanan global. Pembelajaran sosialnya adalah kesadaran ekologis, sosial dan politik-pedagogi makanan untuk keberlanjutan ketersediaan pangan.
\end{abstract}

Kata kunci: Food Vlogger, Globalisasi, Homogenisasi, Interaksi Para Sosial, Pedagogi Makanan 


\section{1 | PENDAHULUAN}

\section{Globalisasi, Hegemonisasi dan Hegemonisasi}

Intisari dari globalisasi adalah pergerakan bebas produk barang, jasa, dan manusia ke seluruh penjuru dunia tanpa batas geografis oleh perusahaan multi nasional. Mobilitas bebas menembus ruang dan waktu ini sebenarnya wujud pengalihan dari wacana imperialisme dan modernisasi agar lebih berkonotasi positif. Ini sebagai kedok untuk menetralisir wajah horor dan menakutkan kolonialisme dan wacana neo-imperialisme yang berfungsi untuk mengaburkan eksploitasi berkelanjutan sebagian besar wilayah dunia oleh beberapa negara adidaya dan perusahaan raksasa transnasional. Ini juga mencakup budaya yang mempromosikan gaya hidup, konsumsi, produk dan identitas yang dilakukan oleh perusahaan multinasional lewat pemanfaatan perangkat periklanan untuk menembus pasar lokal dan menanggulangi resistensi warga setempat (Kellner, 1998). Globalisasi budaya ini papar Suyanto (2013) adalah penetrasi kekuatan dan superioritas budaya Barat yang merambah ke berbagai sendi kehidupan masyarakat yang berakibat pada pembentukan pola konsumsi masyarakat, gaya hidup dan bahkan memengaruhi cara berpikir masyarakat.

Proses penyeragaman budaya dan gaya hidup (homogenisasi) dan hegemonisasi merupakan akibat berikutnya yang tak terelakkan. Keduanya merupakan konsep kembar yang berlangsung simultan. Hegemonisasi menurut Mazrui (1998) adalah konsentrasi kekuasaan yang timpang antara negara atau peradaban tertentu atau menguatnya konsolidasi pusat hegemonik. Sementara homogenisasi adalah proses perluasan homogenitas. Globalisasi telah meningkatkan penyeragaman gaya hidup konsumsi makanan, berpakaian dan hiburan (food, fashion, fun) pada pada warga masyarakat yang berbeda. Namun, tren ini disertai dengan pembagian kekuatan global yang tidak seimbang di antara beberapa negara. Singkat kata, hegemonisasi merupakan proses yang memungkinkan satu budaya mendominasi dan menjadi budaya arus utama pada beberapa bidang kehidupan yang sebelumnya ditempati oleh beberapa budaya tradisional (Gasper, 2010). Tidak hanya itu, komodifikasi juga berlangsung saat menggunakan media baru (Setiyaningsih, \& Jatmikowati, 2019) sehingga globalisasi mampu memadukan hegemoni dan komodifikasi (Olaniyan, \& Akpojivi, 2021).

Wujud globalisasi tersebut adalah homogenisasi gaya hidup menyantap makanan cepat saji yang mewabah nyaris di seluruh penduduk bumi. Gejala ini lebih dikenal dengan istilah McDonalisasi (McDonaldization) yang digagas oleh George Ritzer tahun 1993 hasil penilitiannya terhadap manajemen restoran cepat saji McDonald. Hasil kajiannya yang dipublikasi dalam buku monumental bertajuk The McDonaldization of Society: An Investigation Into The Changing Character of Contemporary Social Life menggambarkan pengelolaan restoran cepat saji berbasis rasionalisasi manajemen moderen ilmiah seperti efisiensi, kalkulasi, penghitungan dan pengawasan (George Ritzer, 2019). Gejala serupa juga terjadi dalam konsumsi minuman kaleng Coca Cola yang disebut dengan Coca Colanisasi / Coca Colonization (Flusty, 2005; Wagnleitner, 2000). Fenomena modernisasi pengelolaan organisasi layanan dan produksi barang ini juga merambah ke sektor yang lain seperti bidang pendidikan tinggi (Hartley, 1995), perpustakaan kampus (Quinn, 2000), profesi layanan sosial (Dustin, 2016), bidang pengobatan (Dorsey, \& Ritzer, 2016), layanan spiritualitas keagamaan (Drane, 2000) bahkan ke bidang penanganan pandemi Covid 19 (G. Ritzer, 2020).

\section{Penyeragaman dan Resistensi Gaya Hidup Makanan Cepat Saji}

Makanan siap saji, menurut wikipedia.id merujuk kepada makanan yang dijual di sebuah restoran atau toko dengan persiapan yang berkualitas rendah dan disediakan kepada pelanggan dalam sebuah bentuk paket untuk dibawa pergi. Makanan ini biasanya diproduksi massal di pabrik yang lantas dibekukan di lemari es besar untuk kemudian dipanaskan kembali serta diberikan rasa buatan dan alami demi memastikan bahwa makanan tersebut memiliki rasa yang sama (Howstuffworks.wiki.id, 2021). Proses tersebut menyebabkan makanan cepat saji rentan terhadap berbagai ragam penyakit mulai dari penyakit kardiovaskular, kanker kolorektal, obesitas, kolesterol tinggi, kondisi resistensi insulin dan depresi (Wikipedia.id, n.d.).

Makanan cepat saji dengan kandungan bahan tidak alami buatan manusia hasil rekayasa 
modifikasi genetika organisme (genetic modification organism) ini telah menjadi menu andalan restoran cepat saji ini dan telah menjadi sumber utama kalori tidak hanya bagi warga Amerika saja tapi juga sebagaian besar populasi bumi. Industri makanan dengan kandungan minim bahan biologis alami yang diproduksi dan dipasarkan secara massal ini tak pelak telah mengundang protes keras para pegiat gizi dan makanan sehat di negara asalnya. Fuhrman, \& Phillips, 2017) menegaskan bahwa makanan ini ditengarai akan menghancurkan potensi manusia, bersama dengan ledakan penyakit kronis, penderitaan manusia, dan kematian dini jutaan orang. Bahkan ini berpotensi mengarah kepada genosida alias "penghancuran yang disengaja atas seluruh ras atau bangsa". Lustig (2017) menyoroti terjadi peretasan (hacking) otak manusia oleh perusahaan farmasi, rokok dan makanan. Ini dilakukan dengan membuat pesan yang disamarkan secara cerdik, disinformasi, propaganda, dan berita palsu. Juga lewat menciptakan kebingungan sistematis dan penggabungan konsep dan definisi kesenangan (pleasure) dan kebahagiaan (happiness) yang dimasukkan ke dalam sistem limbik (bagian emosional) otak. Ini dapat mempercepat ledakan gerak lambat (slowmotion crash) dalam persentase yang cukup besar sehingga memperparah kerugian individu. Buruknya, peretasan ini bukan tidak disengaja tetapi sebenarnya adalah sebuah plot-yaitu, peretasan itu tidak hanya untuk membuat kerusakan melainkan secara khusus dirancang dan direkayasa dengan motif keuntungan. Lustig, (2012) menegaskan bahwa makanan bukan lagi menjadi kebutuhan tapi komoditas imdustri yang dirumuskan ulang menjadi zak adiktif. Walhasil, obesitas menggejala di masyarakat. Lingkungan makan ini sarat racun (poisonous) karena tidak sesuai lagi dengan biokimia tubuh yang lantas akan menimbulkan krisis medis, sosial dan keuangan. Parahnya, "pola makan Amerika" ini sekarang menjadi "pola makan industri global" yang berpotensi membunuh manusia secara perlahan. Ini terjadi karena pemerintah di seluruh dunia telah dikooptasi oleh industri makanan. Fenomena ini biasa disebut penyanderaan regulasi / regulatory capture (Dal Bó, 2006; Stigler, 1971). Juga, untuk memperoleh persepsi positif dan membentukan opini publik positif, indsutri melakukan praktek diskursif yang disebut Smith, \& Tasnadi (2014) sebagai deep capture; berupaya mempengaruhi para politisi, pesohor, media bahkan dan lembaga pendidikan. Kedua fenomena tersebut juga ditemukan Wagnleitner (2000) yang melakukan kajian terhadap proses asimilasi budaya Amerika di Austria menemukan bahwa Amerikanisasi Austria terjadi bukan hanya berkat propaganda massif, kemampuan menempus pasar dan konsumerisme saja. Tapi juga didukung oleh upaya ekonomi politik yang dilakukannya.Ada keterkaitan antara rekonstruksi ekonomi politik demokratisasi Austria dengan proses asimilasi kultural.

Gerakan resistensi terhadap menjamurnya budaya konsumsi makanan cepat saji ini juga digelar oleh warga masyarakat lainnya berupa budaya tandingan. Salah satunya adalah Belasco (1993) menyoroti peran media dalam membentuk opini publik tentang pangan, kesehatan, dan reformasi. la juga mengkritisi bagaimana media menjadi pertempuran atau pusat pergeseran antara pro terhadap makanan yang mengandung radikal bebas dan yang konservatif. Alih-alih menjadi anjing penjaga kepentingan publik, media beralih menjadi anjing peliharaan kapitalis. Meskipun media dipaksa untuk melaporkan pelanggaran industri makanan, media cenderung enggan terlibat mengungkap keburukan bisnis besar secara keseluruhan. Media juga seringkali memberitakan gerakan makanan organik dalam bingkai "kompos dan kepik"'compost and ladybugs dan praktik penipuan. Stereotip ini tidak hanya memaksa petani organik kian terpinggirkan tetapi juga menciptakan kepanikan moral yang akan memicu skeptisisme publik terhadap apa pun yang menantang status quo industri makanan (Wagner, 2007).

Meski demikian, popularitas makanan cepat asal negeri paman Sam ini masih belum terkalahkan oleh kuliner lokal tradional. Data menunjukkan bahwa bisnis restoran cepat saji ini meningkat 15\% tahun 2019 (ekonomibisnis.com, 2019). Sempat mengalami penurunan pada tahun 2015. Tapi hal ini terjadi lebih disebabkan oleh menurunnya daya beli masyarakat akibat melemahnya ekonomi nasional (kontan.co.id., 2015). Penurunan omzet bisnis ini kemudian terjadi tahun 2020 akibat dari program pembatasan sosial karena pandemi Corona (katadata.co.id, 2020). Tidak heran, kalau gaya hidup menyantap makanan siap saji masih tetap masih trendi di kalangan anak muda. Ada lima alasan kenapa demikian. Ini mulai dari cepat mudah didapat dan praktis, menghilangkan stress, kandungan kalori tinggi yang disukai otak manusia, racikan bumbunya membekas di ingatan dan mengandung lemak tinggi yang membuat kecanduan (kumparan.com, 2018). 


\section{Food Vlogger dan Kuliner Tradisional}

Istilah vlog merupakan kombinasi antara kata "blog" dan "vlog" ; gabungan antara kata video dan blog. Blog merupakan format komunikasi tulisan yang berbasis internet atau weblog. Sementara vlog adalah komunikasi berformatkan video yang merekam pikiran, pendapat dan minat seseorang yang dipublikasikan via internet. Keduanya dibuat untuk menjangkau khalayak tertentu oleh seseorang yang berupaya untuk menciptakan sebuah hubungan personal dengan khalayak. Ini sekaligus juga sebagai sarana berbagi pikiran, gagasan, dan pengalaman antara kedua pihak. Vlogger adalah sebutan bagi pencipta vlog (Baker, 2019). Ini adalah sebuah bentuk media penyiaran televisi online yang mulai banyak dimanfaatkan orang seperti YouTube. Beberapa vlogger juga blogger dengan menautkan video yang diciptakan pada blog atau website mereka.

Istilah food vlogger terinspirasi dari "mukbang" siaran makan Korea Selatan yang populer tahun 2017 (idntimes.com, 2018). Di sini sang penyiar menyantap makanan dalam jumlah berlebihan lewat kamera web yang disiarkan dengan menghadirkan banyak orang secara langsung dan interaktif. Siaran ini merupakan bentuk sosialiasi yang menciptakan kesamaan maya (virtual commensality) yang memungkinkan pemirsa untuk memposting komentar dan "menyukai" gambar, suara, dan narasi penyiar saat makan (Aucoin, 2019). Menjamurnya dan berkembangnya food vlogger Indonesia dalam konteks ini berdampak positif dalam mempopulerkan makanan tradisional. Ini mengingat fakta bahwa masyarakat Indonesia pengguna media sosial YouTube terbanyak sebesar Youtube 93,8 \%, Whataps 87,7, Instagram 86,6 \%, Facebook 85,5 \%, Twitter 63,3\%. (Wearesocial.com, 2021).

Nex Carlos adalah salah satu food vlogger ternama nasional. Lokadata.id (2021) menempatkannya peringkat ketiga dari sepuluh pengulas makanan nasional. Peringkat tersebut patut disematkan kepada Nex Carlos karena ia memiliki 4.24 juta subscribers dengan total 963.5 juta penonton di akun Youtube-nya. Jargon "Makan Cuy" dan mengulas makanan tradisional sambil berwisata keliling daerah Nusantara merupakan ciri khususnya. Dengan kata lain, merupakan food vlogger nasional yang menggandrung kuliner lokal tradisional nusantara. Nyaris semua video yang diunggah di akunnya adalah masakan daerah Nusantara. Keberlimpahan informasi tersebut menimbulkan kepanikan dalam penggunaan media (Setiyaningsih, 2020).

Berkaitan dengan konteks tersebut, perlu disadari bahwa urusan menyantap makanan ternyata bukan sekedar urusan mengisi perut untuk memenuhi rasa lapar demi mempertahan hidup seperti pepatah Latin edo, ergo sum (aku makan maka aku hidup). Ini juga terkait dengan proses pembentukan jatidiri dan identitas seseorang yang dikonstruksi oleh budaya (Meigs, 1987). Makanan berarti hasil kreasi budaya yang menetapkan bahan apa, bagaimana cara mengolahnya, cara menyajikan serta mengkonsumsinya (Handayani, 2015; Triono \& Setiyaningsih, 2017). Kuliner juga berfungsi sebagai identitas budaya dan media komunikasi lintas budaya (Utami, 2018). Berdasarkan hal tersebut, penelitian ini berusaha mengkaji efektifitas akun media sosial Nex Carlos dalam mempopulerkan makanan tradisional ke kancah manca negara.

\section{2 | METODE PENELITIAN}

Penelitian ini menggunakan pendekatan deskriptif kualitatif yang memfokuskan pada fungsi food vlogger Nex Carlos dalam mempromosikan kuliner lokal melalui tayangan di kanal Youtube serta proses interaksi antara food vlogger Nex Carlos dengan penontonnya serta pengaruh yang ditumbulkan akibat dari interaksi tersebut. Informan diseleksi berdasarkan kriteria a) audiens yang telah menjadi subscriber satu tahun lebih; dan b) audiens yang bertempat di Kota Palangkaraya Kalimantan Tengah. Ini dilakukan untuk memperoleh data lewat wawancara mendalam. Penelitian ini melibatkan lima orang informan seperti dan pemilihannya berdasarkan kriteria di atas. Teknik pengumpulan data dilakukan dengan metode wawancara mendalam, dokumentasi dan penelusuran pustaka yang relevan. Metode analisis data menggunakan Miles dan Huberman melalui proses data yang terkumpul kemudian dianalis lewat proses reduksi data, penyajian data dan verifikasi data serta penyimpulan (Sugiyono, 2017). 


\section{3 | HASIL DAN PEMBAHASAN}

\section{Profil Food Vlogger Nex Carlos}

Nex Carlos merupakan food vlogger ternama nasional. Lokadata.id (2021) menempatkannya pada peringkat ketiga dari sepuluh food vlogger Indonesia. Wajar gelar tersebut disematkan kepadanya sebab ia memiliki 4.24 juta subscriber dan total 433 video yang sudah diunggah.Socialblade.com (2021) mencatat akun yang dibuat 15 Nopember 2015 sudah ditonton 963.508.050 kali. Lewat motto "Makan Cuy !" plus deskripsi "Hi, nama gw Nex dan gw suka makan! Jadi gw keliling Indonesia buat makan dan mencoba makanan khas di setiap daerah", Carlos dapat disebut sebagai pecinta kuliner lokal Nusantara. Berwisata keliling daerah Indonesia sambil mengulas dan mencicipi masakan khas masing-masing daerah menjadi brand pribadinya sekaligus menjadi daya tarik untuk dilanggan dan ditonton. Tidak heran jika setiap konten video yang diunggahnya ditonton kurang lebih dari 1 juta kali penayangan. Salah satu video unggahannya bertajuk "Cuma Nasi Sama Telor Tapi yang Makan Rame !!!!" yang dibuat 27 Pebruari 2018 sempat viral dengan total jumlah tayangan mencapai 16 juta kali (Nex Carlos, 2018. Caranya mengulas masakan secara apa adanya tanpa terkesan melebih-lebihkan merupakan penciri dan jatidirinya. Keunikannya yang lain adalah memberikan tanda "Gak ada obat" saat mencicipi masakan. Ini melambangkan bahwa kuliner tersebut merupakan kuliner paling enak yang pernah dicicipinya.

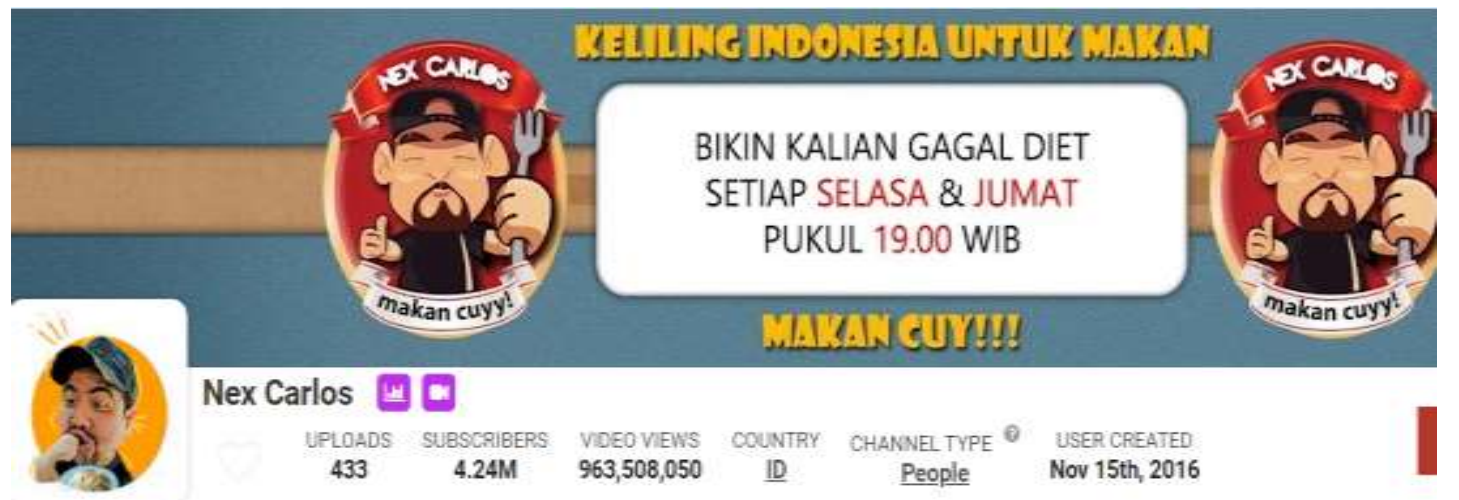

Gambar 1. Profil Channel Youtube Nex Carlos (socialblade.com, 2021)

Berbeda dengan food vlogger lain yang meminati mengulas makanan yang sedang viral alias menjadi perbincangan warga net, Nex Carlos memusatkan perhatiannya dalam mengulas masakah khas daerah. Dengan kata lain, konten video Nex Carlos sarat lokalitas masakan tradisional khas daerah Indonesia. Ini juga personal brand nya dan keunikannya. Lewat tayangan video tersebut, ia setidaknya ingin mengirimkan pesan bahwa masakan Nusantara lebih sesuai dengan selera makan dan daya beli kebanyakan masyarakat Indonesia karena masakan tersebut memanfaatkan bumbu, rempah dan bahan sayuran yang masih segar alami dengan harga yang terjangkau. Ini juga menegaskan bahwa menyantap masakan tradisional lebih sehat karena minim kandungan kimiawi yang ditambahkan di dalamnya. Hal ini bertolak belakang dengan masakan cepat saji yang lebih memiliki gengsi sosial tapi membahayakan kesehatan akibat kandungan senyawa kimiawi yang terdapat di dalamnya.

\section{Nex Carlos dan Globalisasi Masakan Lokal}

Dari paparan di atas dapat disimpulkan bahwa Nex Carlos berperan efektif dalam mempromosikan masakan tradional lokal ke manca negara. Ini seperti ditemukan dari jawaban informan yang menyatakan bahwa efektivitas tersebut dapat dijelaskan sebagai berikut. Pertama, jumlah subscriber dan jumlah penonton yang mencapai jutaan. Informan mengatakan; “...dengan jumlah penayangan tiap video yang mencapai jutaan, tentunya tujuan dalam mempromosikan kuliner lokal tersebut disaksikan oleh banyak orang, tidak hanya orang yang berasal dari daerah dimana kuliner tersebut berasal, tetapi didaerah lainnya juga".... Kedua, dengan jumlah jutaan pelanggan dan penonton tersebut akan mendorong rasa ingin tahu untuk lebih mengenal aneka 
ragam lain masakan daerah. "dia tiba-tiba promosiin makanan lokal secara langsung kan gak Cuma orang lokalnya aja yang tau, orang yang gak pernah lihat juga oh ini kah makanan dari daerah ini, menariklah bisa dicoba"..., jawab informan. Ketiga, informasi variatif dan diperbaharui; ia tidak sekedar menyatakan masakan enak saja tapi juga menyediakan informasi baru berupa menu masakan dari daerah terpencil. Ini ditegaskan informan seraya mengatakan : “... jadi dia gak cuman bilang kalau makanan itu enak, dia juga memberikan informasi baru, lewat thumbnailnya disampaikan hidden gem itukan tempat-tempat terpencil gitu.... Keempat, makanan tradisional dijual dengan harga lebih terjangkau daripada makanan cepat saja yang berada di super market atau mall. Informan menyatakan: "...karena dia ngereview makanan tidak harus makanan mahal dan di mall , tetapi lebih ke yang lokal, jadi recommended kalau kita suka kuliner lokal."

Data statistik subsribers, jumlah tayangan video tersebut merupakan angka dinamis yang akan berkembang sebanding dengan jumlah video tentang keragaman masakan lokal yang diunggah. Data tersebut dipastikan akan terus meningkat yang akan kian memampukan masakan lokal semakin populer dan dikenal oleh masyarakat manca negara. Sebagai media jejaring komunikasi sosial, food vlog berbasis YouTube ini merupakan sarana mengglobalkan masakan tradional Nusantara. Wisatawan manca negara menjadikan food vlog ini sebagai rujukan untuk dan mencari rekomendasi makanan saat mereka berkunjung ke Indonesia (Evelina, \& Safitri, 2021). Kuliner lokal juga berfungsi mempromosikan destinasi wisata nasional bagi wisatawan asing (Primasari, \& Siswojo, 2012). Juga, dapat meningkatkan keunggulan kempetitif destinasi daerah (Pitanatri, 2016).

\section{Interaksi Para Sosial Food Vlogger dan Penonton}

Kehandalan platform vlog terletak pada kemampuannya menghadirkan dan memvisualkan ekspresi wajah, nada suara, emosi, dan bahasa tubuh. Audiens cenderung percaya dengan emosi dan nada vlogger saat mempresentasikan produk yang diulas. Karakteristik interaksi antara pengguna dengan vlogger akan menentukan efektivitas tersebut. Hal ini akan memfasilitasi proses berbagi pengalaman, keluhan, pendapat pribadi dan pemikiran tentang produk yang telah direview. Hubungan kedua belah ini disebut interaksi para sosial/ para sosial interaction ; hubungan antara pengguna dan persona dalam konteks media sosial yang mencakup intensitas hubungan keduanya mengarahkan penonton untuk memandang vlogger sebagai panutan, konselor, penghibur, atau juga sebagai teman (Razak, \& Zulkifly, 2020). Efektivitas media komunikasi jejearing sosial dalam mempromosikan kuliner lokal juga difasilitasi oleh adanya interaksi intim antara food vlogger dengan penontonnya atau biasa disebut interaksi para sosial / para social interaction (PSI). Ini merupakan bentuk interaksi antara audiens dan persona media dan umumnya ditandai dengan perasaan kedekatan antara audiens dengan karakter yang dihadirkan membumi "down to earth". Intinya adalah "keintiman di kejauhan" intimacy from distance yang menunjukkan rasa keintiman bersama yang sepihak dan termediasi (Cohen, 2014).

Singkat kata, interaksi para sosial merupakan "hubungan tatap muka yang tampak" antara pemirsa dan tokoh media ; ikatan afektif yang berkembang antara kedua pihak ; relasi sosial nyata. Interaksi online dapat memperdalam ikatan tatap muka yang ada dan juga dapat mengarah pada pembentukan hubungan baru yang sering kali dekat dan saling menguntungkan. Dengan demikian, tampak bahwa hubungan dengan tokoh media dan aspek sosial dari penggunaan Internet memenuhi (sebagian) kebutuhan manusia yang mendalam akan afiliasi sosial, dan juga memainkan peran penting dalam pengembangan identitas (Hoffner, 2008).

Interaksi para sosial yang terjadi mengarahkan penonton untuk memandang Nex Carlos sebagai model panutan, konselor untuk mencari bimbingan, dan penghibur. Karakteristik pribadi ini mengakibatkan perubahan sikap dan perilaku untuk mengadopsi makanan yang direkomendasikannya. Interaksi para sosial ini telah membuat mereka tertarik untuk mencoba menyantap kuliner lokal dan mengadopsi rekemendasi food vlogger (Ardrini et al., 2020; Chen, 2021; Hapsari, 2019; Miranda, 2019; Razak, \& Zulkifly, 2020; Triono \& Setiyaningsih, 2017). Hal ini telah mampu "menyihir" penontonnya untuk mengkonsumsi makanan yang diulas dan direkomendasikanya.

Dapat disimpulkan bahwa food vlogger berperan penting dalam mempromosikan dan mengglobalkan masakan tradisional. Ini didukung adanya komunikasi jejaring sosial via kanal 
Youtube yang berbasis media baru (new media). Berbeda dengan media lama, media baru merupakan gabungan media komunikasi dengan teknologi telekomunikasi. Komunikasi yang terjadi dipermudah oleh komputer yang berjejaring internasional; komunikasi yang dimediasi komputer; computer mediated communication. Unsur media baru terdiri dari : 1) Digitalisasi dan konvergensi semua aspek media ; 2) Interaktivitas dan konektivitas jaringan yang meningkat; 3) Mobilitas dan delokasi pengiriman dan penerimaan ; 4) Adaptasi publikasi dan peran khalayak; 5) Munculnya aneka bentuk gateway media (McQuail, 2010).

\section{Makanan Sebagai Produk Budaya dan Simbol Komunikasi}

Makanan lokal berkaitan mengkonsumsi masakan yang berasal dari bahan tradional alami dengan aturan penyajian tertentu yang telah ditetapkan budaya lokal. Kuliner lokal makanya merupakan hasil kreasi budaya. Ini menggambarkan dan melambangkan identitas komunitas lokal sekaligus sumber penandaan serta bentuk komunikasi yang efektif dari budaya yang khas (Utami, 2018). Keragaman bahan makanan, teknik mengolah bahan, kepercayaan dan norma yang melingkupi kuliner lokal membentuk sebuah jaringan sistem yang saling terkait. Ini adalah sebuah bentuk komunikasi yang efektif (Parasecoli, 2011). Makanan Pecel menurut budaya Jawa melambangkan kesederhaan, kedekatan dengan rakyat atau kerendahan hati, dan spiritualitas seseorang. Simbol ini dimanfaatkan oleh calon pemimpin daerah dan nasional sebagai bentuk komunikasi politik dalam kontestasi politik (Wulandari, 2020).

Untuk memelihara warisan budaya ini diperlukan gerakan promosi tentang pengetahuan makanan tradisional/ traditional food knowledge (TFK). Ini merujuk pada tradisi budaya berbagi makanan, resep dan keterampilan dan teknik memasak dan mewariskan kebijaksanaan kolektif itu dari generasi ke generasi. Ini menjadi sarana memperkokoh identitas budaya lewat menghubungkan manusia dengan alam natural; mengembangkan tata kehidupan yang berkelanjutan, kesehatan ekosistem dan peningkatan kapasitas individu dan masyarakat. Ini dapat memampukan seseorang untuk menyiapkan makanan yang bergizi, aman dan relevan secara budaya. Hal ini penting agar dapat beradaptasi terhadap lingkungan makanan yang berubah (Kwik, 2008). Media lokal lewat penyajian program yang sarat dengan warna lokalitas dapat mengambil peran dalam hal ini (Setiyaningsih, 2016).

\section{Budaya Tandingan dan Glokalisasi Kuliner Lokal}

Fenomena kian berkembangnya masakan tradisional dalam budaya nasional kontemporer menggambarkan tuntutan masyarakat akan makanan yang sehat sekaligus membentuk budaya tandingan (Kim, 2014) yang dimaksudkan untuk menahan genjarnya dan popularitas masakan global cepat saji. Budaya konsumsi ini merupakan tempat istimewa bagi pembentukan jati diri dan masyarakat dan pengembangan masyarakat dan identitas (Comaroff, \& Comaroff, 2000). Memperkuat keterlibatan budaya khas daerah, kearifan lokal dan nilai-nilai masyarakat setempat yang bertujuan untuk memelihara dan memberdayakan identitas merupakan pendekatan dari bawah untuk menghadapi proses globalisasi (Salleh, 2017). Ini karena kian meningkatnya saling keterkaitan yang tercipta akibat dari proses globalisasi telah mendorong masyarakat untuk mengakui pentingnya perasaan kemanusiaan bersama lantas berupaya secara bersama untuk menangai masalah global yang mendesak. Ini membutuhkan pengembangan pemahaman yang lebih bernas dan komprehensif tentang perbedaan budaya dan psikologi warga setempat (Melluish, 2014). Globalisasi memang telah mengakibatkan homogenisasi budaya dan gaya hidup pada sebagian warga dunia. Tapi juga menimbulkan heterogenisasi dan hibridisasi (Hassi, \& Storti, 2012). Dengan kata lain, gejala ini disebut sebagai glokalisasi (istilah gabungan antara globalisasi dan lokalisasi) yakni kemunculan secara simultan kecenderungan universalisasi dan partikularisasi dalam sistem sosial, politik, dan ekonomi kontemporer. Ini merupakan kecenderungan menuju homogenitas dan sentralisasi muncul bersamaan dengan kecenderungan menuju heterogenitas dan desentralisasi; keterkaitan tingkat global dan lokal (Blatter, 2013). 


\section{Pedagogi Makanan/ Food Pedagogy}

Makanan bukan sekedar berurusan dengan menyantap masakan yang bernutrisi sehat dari bahan baku alami seperti yang ditetapkan budaya. Gaya hidup konsumsi masakan kuliner lokal ini lantas dijadikan sebagai budaya tandingan untuk menepis arus deras budaya konsumsi masakan cepat saji global. Ini memang akan mengakibatkan terbentuknya kesadaran kultural lokal yang berperan penting untuk memelihara identitas budaya. Tapi juga terkait makanan juga berkaitan dengan aspek sosial, ekonomi dan politik. Kompleksitas masalah meliputi kebijakan konsumsi, kesehatan warga, produksi dan ketersediaan pangan dan penyediaan pangan yang berkelanjutan. Di sini terihat pentingya pedagogi makanan (food pedagogy) yang meliputi relasi sosial, budaya, gaya hidup berkelanjutan, ruang pembelajaran terkait dengan masalah makanan. Konsep 'pedagogi makanan' merujuk pada penyelenggaraan pengajaran dan pembelajaran tentang makanan, diversifikasi proses pendidikan makanan, munculnya pendidik makanan baru dan pergeseran keahlian dan pengetahuan tentang makanan beserta keterkaitannya dengan masalah sosial, politik dan kultural.

Singkat kata, makanan terkait dengan tindakan manusia yang rasional, perilaku relasional manusia serta isu kultural dan pendidikan. Urusan makanan itu multidimensi yang menyangkut aspek sosial kultural, lingkungan, kesehatan dan politik. Tidak hanya itu, ini berhubungan dengan perilaku komunikasi. Cara makan seseorang menggambarkan cara ia berkomunikasi. Komunikasi yang baik, makanya diperlukan untuk mengembangkan kebiasaan makan yang lebih baik. Untuk mewujudkan ini, maka perlu dikembangkan pedagogi makanan (pedagogy of food). Hal ini mengingat fakta bahwa mengkonsumsi makanan adalah tindakan relasional sementara pendidikan itu didasarkan pada hubungan antar manusia. Lewat kemampuan menafsirkan dimensi simbolis makanan, seseorang akan mampu mengembangkan kepekaan moral (Valera, \& Russo, 2018).

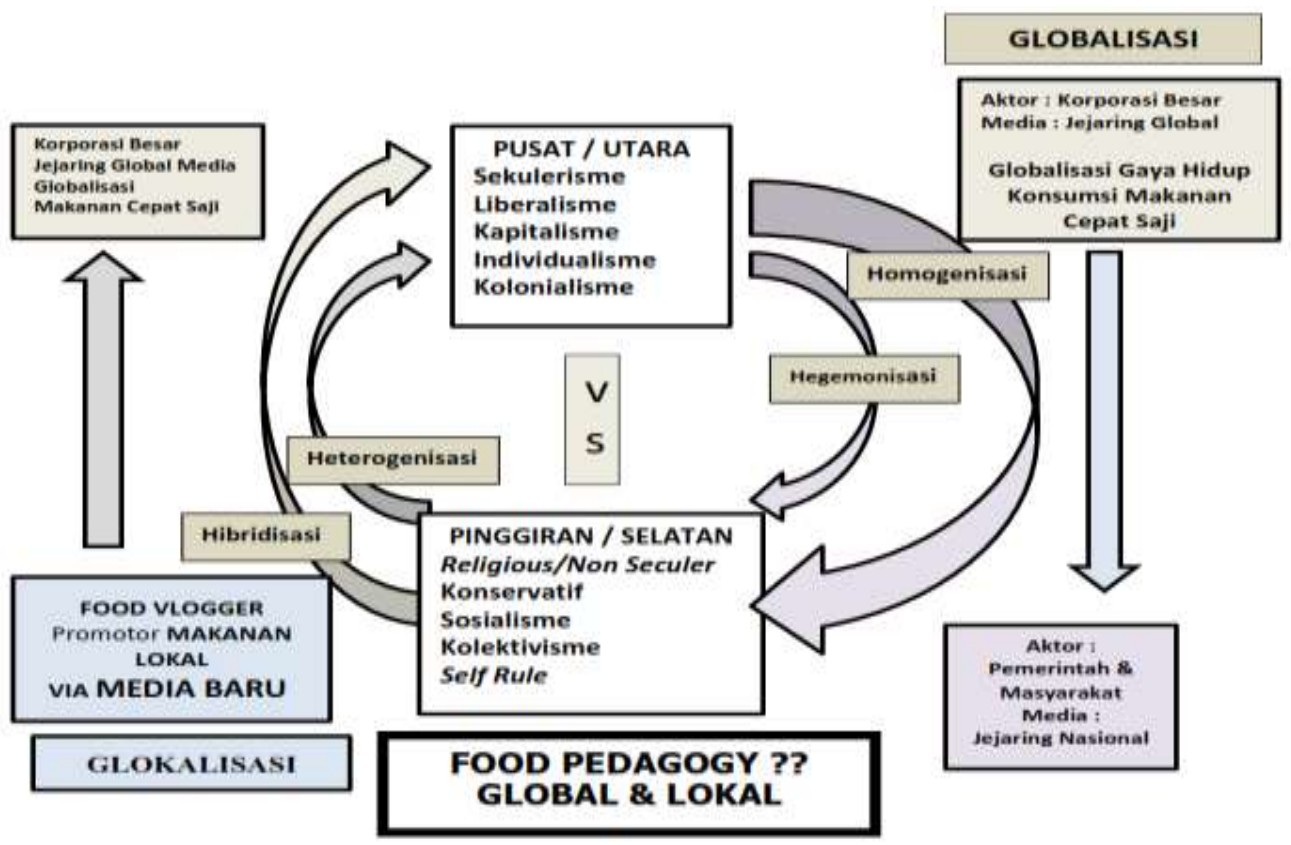

Gambar 2. Globalisasi - Glokalisasi Kuliner Lokal oleh Food Vlogger (Valera, \& Russo, 2018)

Pedagogi makanan yang biasanya beraliran kritis didefinisikan sebagai proses pembelajaran experinsial untuk meningkatkan pengetahuan dan ketrampilan berinteraksi tentang permasalahan terkait makanan. Ini lantas dipadukan dengan metode berpikir kritis, penyajian solusi terhadap permasalahan makanan yang dimaksudkan agar pembelajar mampu menjadi hubungan kekuasaan. Dengan menerapkan teori pembelajaran experiensial, pendidikan tentang keberlanjutan, teori pembelajaran orang dewasa, pedagogi pangan kritis berusaha mempermasalahkan perebutan kekuasaan sosial, lingkungan, dan ekonomi. Ini karena hal tersebut berkaitan dengan dinamika sistem pangan dan keadilan sosioekologis pangan. Materi pembelajarannya mencakup isu-isu seperti ketahanan pangan; kedaulatan pangan; globalisasi; penindasan; literasi makanan; kesehatan termasuk kelaparan dan obesitas (Lewis B., 2019). 


\section{4 | SIMPULAN DAN SARAN}

Globalisasi perpanjangan kolonialisme mengakibatkan homogenisasi gaya hidup, melalui kecerdikan persuasif perangkat periklanan-diskursif (deep capture) dan usaha lobi politik pemerintahan (regulatory capture). Makanan cepat saji yang berbahaya bagi kesehatan menjadi tren gaya hidup global dengan gengsi sosial ekonomi.Hal ini mendistorsi makna masakan tradisional sebagai produk kreasi budaya yang berfungsi sebagai identitas kolektif masyarakat lokal. Makanan tradisional dilihat sebagai kuliner pinggiran, melalui Food vlogger Nex Carlos mampu mengangkat makna kulturalnya. Hal ini didianggap sebagai budaya tandingan terhadap gencarnya propaganda makanan cepat saji global. Globaliasi menimbulkan homogenisasi, heteroginasi, dan hibridisasi. Diperlukan kesadaran yang komprehensif yang mencakup aspek ekologis, sosial kultural, politik dan ekonomi. Kesadaran tersebut disebut sebagai pedagogi makanan (food pedagogy) untuk internalisasi nilai kepada masyarakat. Berdasarkan hal tersebut, penelitian ini menyarankan sebagai berikut. (1). Menggencarkan kampanye makanan tradisional sebagai warisan budaya dan identitas lokal sekaligus sebagai branding destinasi wisata lokal tertentu. (2). Mempromosikan pembelajaran memasak secara informal dan formal yang dibingkai dalam perspektif pedagogi makanan. Peran ini dapat diambil oleh media, lembaga swadaya masyarakat, dan kampus. Media yang telah memiliki program/ rubrik makanan atau memasak perlu untuk mengadopsi perspektif pedagogi makanan sehingga ada unsur edukasi tentang keberlanjutan kehidupan dan kesehatan. (3). Lebih memperbanyak dan memperluas kajian media dan makanan yang dikaitkan dengan kesehatan (healthy eating) serta menerapkan persepktif pedagogi makanan.

\section{REFERENSI}

Ardrini, D. A. M., Lubis, D., \& Utami, N. W. A. (2020). “I want what they're eating”: College students' experiences in watching food content on YouTube. Public Health and Preventive Medicine Archive (PHPMA), 8(1), 11-16. https://www.phpmajournal.org/index.php/phpma/article/viewFile/249/412\%0A

Aucoin, J. (2019). Virtual Commensality: Mukbang and Food Television. [McGill University, Montreal, Canada]. https://escholarship.mcgill.ca/downloads/k930c256p

Baker, A. (2019). What Is A Vlog - The Real Vlog Meaning \& Definition. https://contentcareer.com/blog/what-is-a-vlog-the-real-vlog-meaning-definition/

Belasco, W. (1993). Appetite for Change: How the Counterculture Took on the Food Industry. Cornell University Press, Ithaca.

Blatter, J. (2013). Glokalisasi. Ensiklopedia Britannica. https://www.britannica.com/topic/glocalization

Chen, C. (2021). Does Watching Others Eat In Videos Make You Buy? Food Eating Videos And Their Relationships to Food Purchase. [Concordia University.]. https://spectrum.library.concordia.ca/988071/

Cohen, J. (2014). Mediated relationships and social life: Current Research On Fandom, Parasocial Relationships, And Identification. Media and Social Life: Electronic Media Research, Routledge, London, 142-156.

Comaroff, J., \& Comaroff, J. L. (2000). Millennial Capitalism: First Thoughts on a Second Coming. Public Culture, 12(2), 291-343. https://doi.org/https://doi.org/10.1215/08992363-12-2-291

Dal Bó, E. (2006). Regulatory capture: A review. Oxford Review of Economic Policy, 22(2), 203225. https://doi.org/10.1093/oxrep/grj013

Dorsey, E. R., \& Ritzer, G. (2016). The McDonaldization of Medicine. JAMA Neurology, 73(1), 1516. https://doi.org/doi: https://doi.org/10.1001/jamaneurol.2015.3449

Drane, J. W. (2000). The McDonaldization of The Church: Spirituality, Creativity, And The Future of The Church . Darton Longman \& Todd.

Dustin, D. (2016). The McDonaldization of Social Work. Routledge.

ekonomibisnis.com. (2019). Bisnis Restoran Cepat Saji Berpeluang Tumbuh 15\%. Ekonomibisnis. Com. https://ekonomi.bisnis.com/read/20190211/12/887488/bisnis-restorancepat-saji-berpeluang-tumbuh-15-tahun-ini. 
Evelina, L. W., \& Safitri, Y. (2021). Utilization of YouTube Social Communication Networking in Establishing Indonesian Street Food Opinion. Jurnal Komunikasi Ikatan Sarjana Komunikasi Indonesia, 6(1), 44-52. http://jurnal-iski.or.id/index.php/jkiski/article/download/406/122

Flusty, S. (2005). De-coca-colonization: Making The Globe From The Inside Out. Routledge.

Fuhrman, J., \& Phillips, R. B. (2017). Fast Food Genocide. How Processed Food is Killing Us and What We Can Do About it. Harper Collins Publishers.

Gasper, E. (2010). Culture, Society \& Globalization: Cultural Homogenization Grades5-8. Classroom Complete Press.

Handayani, T. H. W. (2015). Makanan Sebagai Produk Budaya Dalam Menghadapi Persaingan Global. Prosiding Seminar Nasional 2015 "Pengembangan SDM Kreatif Dan Inovatif Untuk Mewujudkan Generasi Emas Indonesia Berdaya Saing Global" Jurusan. https://journal.uny.ac.id/index.php/ptbb/article/download/31911/13577

Hapsari, Z. H. (2019). Pengaruh Review Food Blogger Javafoodie Terhadap Minat Berperilaku Konsumen Kuliner Di Yogyakarta [Universitas Islam Indonesia]. https://dspace.uii.ac.id/bitstream/handle/123456789/13980/Full Tesis.pdf?sequence $=1$ \&isAllowed $=y$

Hartley, D. (1995). The 'McDonaldization'of Higher Education: Food For Thought? Oxford Review of Education, 21(4), 409-423. https://doi.org/https://doi.org/10.1080/0305498950210403

Hassi, A., \& Storti, G. (2012). Globalization and Culture: The Three H Scenarios. Cuadra-Montiel, H. (Ed.). In Globalization-Approaches to Diversity.

Hoffner, C. (2008). Parasocial And Online Social Relationships. Children, Media, and Development, 309-333. https://doi.org/https://doi.org/10.1002/9781444302752.ch14

Howstuffworks.wiki.id. (2021). Cara Kerja Fast Food - Makanan yang Diproduksi Secara Massal. Howstuffworks.Wiki.Id. https://howstuffworks.wiki/id/ilmu/inovasi/inovasi-yang-dapatdimakan/fast-food1

idntimes.com. (2018). 7 YouTuber Mukbang asal Korea, Bisa Jadi Inspirasi Food Vlogger Nih! Idntimes.Com. https://www.idntimes.com/food/dining-guide/putriana-cahya/7-youtubermukbang-korea-1/7

katadata.co.id. (2020). Omzet KFC dan McD Merosot di Tengah Pembatasan Sosial Pandemi Corona. Katadata.Co.Id. https://katadata.co.id/agustiyanti/berita/5e9a41f73c890/omzet-kfcdan-mcd-merosot-di-tengah-pembatasan-sosial-pandemi-corona

Kellner, D. (1998). Globalization and the Postmodern Turn. In Globalization and Europe. Globalization and Europe.

Kim, J. (2014). The Reinvention of Traditional Cuisine as Counterculture. The Journal of the Korea Contents Association, 14(11), 944-954. https://doi.org/https://doi.org/10.5392/JKCA.2014.14.11

kontan.co.id. (2015). Bisnis penjualan makanan cepat saji turun 5\%-10\%. Kontan.Co.ld. https://industri.kontan.co.id/news/bisnis-penjualan-makanan-cepat-saji-turun-5-10

kumparan.com. (2018). Ini 5 Alasan Mengapa Fast Food Sangat Digemari. Kumparan.Com. https://kumparan.com/kumparanfood/ini-5-alasan-mengapa-fast-food-sangat-digemari1535025951813895673/full

Kwik, J. C. (2008). Traditional Food Knowledge: Renewing Culture and Restoring Health. University of Waterloo Ontario Canada.

Lewis B., O. J. K. (2019). Critical Food Pedagogy and Sustainable Development. Sustainability in Higher Education, 45(2), 345-352. https://doi.org/https://doi.org/10.1007/978-3-030-113520253

lokadata.id. (2021, April 2). Makan enak, duit banyak, ini Top 10 Food Vloggers Indonesia. Lokadata.Id. https://lokadata.id/artikel/makan-enak-duit-banyak-ini-top-10-food-vloggers

Lustig, R. H. (2012). Fat Chance: Beating the Odds Against Sugar, Processed Food, Obesity, and Disease. Hudson Street Press.

Lustig, R. H. (2017). The Hacking of the American Mind: The Science Behind the Corporate Takeover of Our Bodies and Brains. Avery.

Mazrui, A. A. (1998). Globalization, Islam, and the West: Between Homogenization and Hegemonization. American Journal of Islam and Society, 15(3), 1-13. https://doi.org/https://doi.org/10.35632/ajis.v15i3.2171

McQuail, D. (2010). Mass Communication Theory, 6th Edition. Sage Publications. 
Meigs, A. (1987). Food as a cultural construction. Food and Foodways, 2(1), 341-357. https://doi.org/https://doi.org/10.1080/07409710.1987.9961926

Melluish, S. (2014). Globalization, culture and psychology. International Review of Psychiatry, 26(5), 538-543. https://doi.org/https://doi.org/0.3109/09540261.2014.918873

Miranda, G. L. (2019). Pengaruh Atribut Vlogger Terhadap Content Sharing Intention, Sikap Terhadap Produk Dan Niat Beli (Studi pada penonton food vlog Youtube). UAJY.

Olaniyan, A., \& Akpojivi, U. (2021). Transforming communication, social media, counter-hegemony and the struggle for the soul of Nigeria. Information, Communication \& Society, 24(3), 422437.

Parasecoli, F. (2011). Savoring semiotics: food in intercultural communication. Social Semiotics, 21(5), 645-663. https://doi.org/https://doi.org/10.1080/10350330.2011.578803

Pitanatri, P. D. S. (2016). Inovasi dalam kompetisi: usaha kuliner lokal menciptakan keunggulan kompetitif di Ubud. Jurnal Master Pariwisata (JUMPA), 3(1), 1-14. https://ojs.unud.ac.id/index.php/jumpa/article/download/23026/15156

Primasari, A., \& Siswojo, T. (2012). Promosi Kuliner Lokal sebagai Daya Jual Pariwisata Indonesia untuk Backpacker Asing.,. Jurnal Tingkat Sarjana Bidang Seni Rupa Dan Desain, 1(1).

Quinn, B. (2000). The McDonaldization of academic libraries?. College \& Research Libraries, 61(3), 248-261. https://doi.org/https://doi.org/10.5860/crl.61.3.248

Razak, N. I. A., \& Zulkifly, M. I. (2020). The Impacts of Food Vlog Attributes On Para-Social Interaction And Customers' Response Behaviours. Journal of Tourism, Hospitality \& Culinary Arts, 12(1), 435-445. https://fhtm.uitm.edu.my/images/jthca/Vol12lssue1/Chap_30.pdf

Ritzer, G. (2020). McDonaldization in the Age of COVID-19. In Ryan, J.M., 2020, COVID-19 Global Pandemic, Societal Responses, Ideological Solutions. Routladge.

Ritzer, George. (2019). The McDonaldization of Society Into the Digital Age Ninth Edition. Sage Publications.

Salleh, M. S. (2017). Facing Globalisation From Below: A Theoretical Construct. Prosiding Strengthening Local Communities Facing The Global Era, 1(1). http://jurnal.unmuhjember.ac.id/index.php/pslct/article/download/885/701

Setiyaningsih, L. A., \& Jatmikowati, S. H. (2019). Media Baru Dalam Komodifikasi Waktu Luang Ibu Rumah Tangga. ETTISAL: Journal of Communication, 4(1), 23-32.

Setiyaningsih, L. A. (2016). Desain Konsep Tentang Konten Lokal Pada Televisi Lokal Untuk Mengembangkan Wisata Kuliner Kota Malang. Jurnal Nomosleca, 2(2), 1-19. https://doi.org/10.26905/nomosleca.v2i2.1198

Setiyaningsih, L. A. (2020). MEDIA PANICS IBU RUMAH TANGGA SETELAH MENGAKSES BERITA COVID-19 (2020). Jurnal Nomosleca, 6(2), 101-110. http://jurnal.unmer.ac.id/index.php/n/article/view/4721/2594

Smith, T. G., \& Tasnadi, A. (2014). The Economics of Information, Deep Capture, and the Obesity Debate. American Journal of Agricultural Economics, 96(2), 533-541. https://doi.org/https://doi.org/10.1093/ajae/aat113

socialblade.com. (2021). YouTube Nex Carlos. Socialblade.Com. https://socialblade.com/youtube/c/nexcarlos

Stigler, G. J. (1971). The Theory of Economic Regulation. Bell Journal of Economics and Management Science, 2(1), 3-21. https://doi.org/https://doi.org/10.2307/3003160

Sugiyono. (2017). Metode Penelitian Kuantitatif, Kualitatif, dan R\&D. CV. Alfabeta.

Suyanto, B. (2013). Sosiologi Ekonomi. Kencana.

Triono, M. A., \& Setiyaningsih, L. A. (2017). Desain Disonansi Kognitif Sebagai Faktor Anteseden Untuk Penguatan Kualitas Informasi Pada Website. Seminar Nasional Sistem Informasi, 1(1), 71-79. http://eprints.unmer.ac.id

Utami, S. (2018). Kuliner Sebagai Identitas Budaya: Perspektif Komunikasi Lintas Budaya. CoverAge: Journal of Strategic Communication, 8(2), 36-44. http://journal.univpancasila.ac.id/index.php/coverage/article/download/588/332

Valera, L., \& Russo, M. T. (2018). Edo, Ergo Sum: Anthropological, Ethical and Educational Considerations About Eating. Persona y Bioética, 22(1), 18-28. http://www.scielo.org.co/pdf/pebi/v22n1/0123-3122-pebi-22-01-00018.pdf

Wagner, D. (2007). Appetite for Change: How the Counterculture Took on the Food Industry. 
Culture \& Agriculture, 29(2), 121-122.

https://doi.org/https://doi.org/10.1525/cag.2007.29.2.121

Wagnleitner, R. (2000). Coca-colonization and the Cold War: the cultural mission of the United States in Austria after the Second World War. Univ of North Carolina Press.

Wearesocial.com. (2021). Most-Used Media Platform Indonesia 2021. Wearesocial.Com. https://datareportal.com/reports/digital-2021-indonesia

Wikipedia.id. (n.d.). Fast Food. Wikipedia.Id. https://en.wikipedia.org/wiki/Fast_food

Wulandari, I. (2020). Pecel, A Political Communication Semiotic Analysis of Javanese Traditional Food As a Dish for Indonesian Politicians. PCCS 2019: Proceedings of the 1st Padjadjaran Communication Conference Series, PCCS 2019. https://doi.org/10.4108/eai.9-102019.2291109 